\title{
A Rapid Assessment of the Water Pollution Status in the An-Shun Urban Drainage Channel, Taiwan
}

\author{
Robby Yussac Tallar ${ }^{1}$, Nikodemus Leomitro ${ }^{1}$, Pin-Han Kuo ${ }^{2}$, and Petr Skada ${ }^{3}$
}

\begin{abstract}
Wastewater treatment plant is the common approach to improve water quality in urban areas. The purposes of this paper are: (i) to investigate some relevant chemical, physical, and ecological variables in the An-Shun Channel, Tainan, Taiwan, and (ii) to evaluate the improvement in operation of the An-Shun Wastewater Treatment Plant in compliance with its design and the short-term and long-term performance by using the Post Project Appraisals (PPAs). The intended purpose of this paper is to provide a rapid assessment of the water pollution status of the An-Shun Channel from chemical, physical, and ecological evidence. It is necessary to integrate the rehabilitation of the An-Shun Drainage Channel with the Urban Planning Process. The quality of water in the An-Shun Drainage Channel cannot improve by itself, so the stakeholders should initiate some water quality improvement programs and maintain a strong cooperation between them.
\end{abstract}

Keywords-PPAs, Urban Drainage Channel, Wastewater Treatment Plant, Water Quality.

\section{INTRODUCTION}

$\mathrm{T}$ HE rapid population growth, unplanned urbanization, and increased industrial and socio-economic developments have become critical contemporary problems all over the world [1]. These problems pose increasing adverse impacts on the natural environment. This situation calls for more government efforts to prevent or minimize the negative impacts on human life. One of the common and critical impacts to the human life is the polluted river and water channel. In this respect, a number of wastewater treatment plants have been constructed in urban areas in recent years to improve the water quality of the polluted channel. The methods commonly used to assess the water quality of aquatic systems that receive discharges of residues from domestic, industrial, and agricultural sources are based principally on measuring the level of the dissolved oxygen in polluted water [2]. These conventional methods are not sufficient to describe the pollution status because the pollutants in the study site come from many contributing sources. About $70 \%$ of the land in this area has been used for agriculture, animal grazing, and manufacturing industries. The high pollution resulting from these land uses creates various types of pollutions that may be

Robby Yussac Tallar and Nikodemus Leomitro $^{1}$ are with the Civil Engineering Department, Maranatha Christian University, Bandung, 40164 INDONESIA

Pin-Han $\mathrm{Kuo}^{2}$ is with the Hydraulic and Ocean Engineering Department, National Cheng Kung University, Tainan, 701 TAIWAN.

Petr $\mathrm{Skada}^{3}$ is with the Civil Engineering Department, National Cheng Kung University, Tainan, 701 TAIWAN. present in different physical and chemical forms in the AnShun Channel [3].

The purposes of this paper are: (i) to investigate some relevant chemical, physical, and ecological variables in the An-Shun Channel, Tainan, Taiwan, and (ii) to evaluate the improvement in operation of the An-Shun Wastewater Treatment Plant in compliance with its design and the shortterm and long-term performance by using the Post Project Appraisals (PPAs). The intended purpose of this paper is to provide a rapid assessment of the water pollution status of the An-Shun Channel from chemical, physical, and ecological evidence. Moreover, based on the Logical Framework Approach and SWOT Analysis, this paper will establish a recommendation for improvement and management of the AnShun Channel and its wastewater treatment plant.

\section{STUDY AREA}

\section{A. General Description}

The An-Shun Drainage Channel is a part of the Jia-Nan Drainage Channel of the Yan-Shuei River Watershed Area in Tainan, Taiwan (Figure 1). The length and the watershed area of An-Shun Drainage Channel are approximately $10 \mathrm{~km}$ and 2090 ha, respectively. Based on the collected data, a map of the land-use distribution in An-Shun Drainage Channel is shown in Figure 2. The agricultural and industrial uses amount to about $40 \%$ and $30 \%$, respectively, of the area. The residential and commercial usage takes up $20 \%$ of the area, with the fish and animal (swine) farming occupying about $10 \%$.

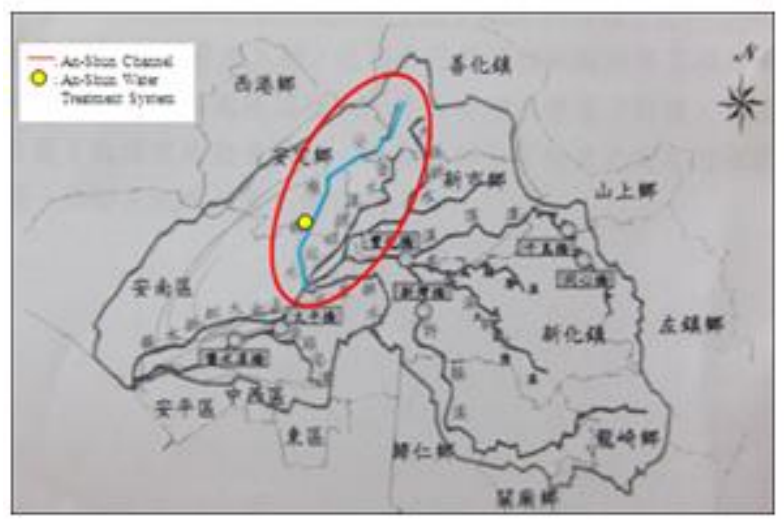

Fig. 1 Location of An-Shun Drainage Channel. (Source: Tainan City Government Report, 2009) 


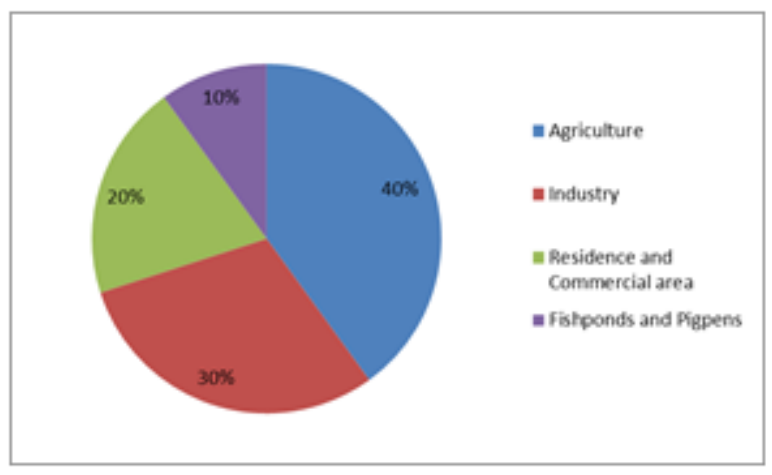

Fig. 2 Land Use Distribution in An-Shun Area

In this study area, there exists a wastewater treatment system called the An-Shun Wastewater Treatment Plant, as shown in Fig. 1. The plant is located close to the An-Shun Drainage Channel, occupying a total area of about 0.4 ha. The main components of the plant are a rubber-made dam, a pumping station, sedimentation tanks, contact aeration tanks, a sludge thickener, a sludge-drying bed, a surface-water wetland, a subsurface-flow wetland, and the grass ditch.

\section{METHOD}

The Post Project Appraisal (PPA) is an evaluation of the effectiveness of the restoration projects based on systematic data collection [4]. Tompkins and Kondolf (2007) proposed a PPA flowchart with seven components, the success criteria, the pre-project surveys, the design rationale, the design drawing, the as-building drawings, the post-project monitoring, and the performance assessment. The results from PPA allow one to learn and retain knowledge from the project experiences, understand how the project is completed, identify areas to improve, and evaluate the project achievement [5].

\section{RESULTS AND DISCUSSIONS}

\section{The Land Use Assessment}

By aid of a map showing the various land uses in An-Shun Drainage Channel in Figure 2, the recognized problems and their primary causes in the An-Shun Drainage Channel can be evaluated (Table I).

TABLE I

The Associated Problems AND CAUSES Under VARIOUS LAND USE IN THE STUDY AREA

\begin{tabular}{llll}
\hline \hline Land Use & Potential Problems & $\begin{array}{l}\text { Possible } \\
\text { Causes }\end{array}$ & Associated \\
\hline Agricultu-re & $\begin{array}{l}\text { Chemical runoffs } \\
\text { (pesticides);Organic } \\
\text { wastes entering the } \\
\text { channel }\end{array}$ & $\begin{array}{l}\text { Poor farming practices } \\
\text { causing an excessive } \\
\text { erosion of the sediment; } \\
\text { Inefficient } \\
\text { swamps and marshes for } \\
\text { farmland }\end{array}$ \\
Industry & $\begin{array}{l}\text { Chemical wastewater } \\
\text { (heavy metals, nutrients, }\end{array}$ & $\begin{array}{l}\text { Poor water quality in the } \\
\text { channel } \\
\text { physical parameters) }\end{array}$ \\
& $\begin{array}{l}\text { and pollutions ); Other } \\
\text { pollutions (suspended } \\
\text { solids and organic } \\
\text { pollutants }\end{array}$ & $\begin{array}{l}\text { (including } \\
\text { Animal } \\
\text { grazing (fish } \\
\text { pond }\end{array}$ \\
\hline
\end{tabular}

\begin{tabular}{|c|c|c|}
\hline swine) & pipes & $\begin{array}{l}\text { farm animals with access } \\
\text { to waterways or wastes } \\
\text { entering the channel as a } \\
\text { runoff }\end{array}$ \\
\hline $\begin{array}{l}\text { Residence, } \\
\text { commercial } \\
\text { area }\end{array}$ & $\begin{array}{l}\text { Excess water and } \\
\text { chemical runoffs, runoff } \\
\text { fertilized and impervious } \\
\text { cover; Reduction of the } \\
\text { vegetation shaded water; } \\
\text { Organic wastes; } \\
\text { Sediment and suspended } \\
\text { solids }\end{array}$ & $\begin{array}{l}\text { Urbanization leads to an } \\
\text { increased land-use } \\
\text { conversion; Shade trees } \\
\text { and shrubs in watershed } \\
\text { removed for the } \\
\text { commercial/industrial } \\
\text { development, exposing the } \\
\text { water to direct sunlight and } \\
\text { increasing the runoff of } \\
\text { sediments and SS into a } \\
\text { body of water }\end{array}$ \\
\hline
\end{tabular}

\section{The Habitat Assessment}

Based on the field survey and data collection, the water in the An-Shun Drainage Channel is severely polluted. The habitat condition is closely related with this situation. Fishes are also selected as the biological indicator to assess the habitat condition [6]. Based on the database of fishes in Taiwan, some fishes were predicted to appear in the An-Shun Drainage Channel. The predicted species of fish are Tilapia zillii; Carassius auratus; Cyprinus carpio; or Zacco pachycephalus.

\section{The An-Shun Wastewater Treatment Plant Assessment}

The design of the An-Shun Wastewater Treatment Plant selects three variables; BOD, SS and DO, to assess the performance of this plant. The monitoring data are shown in Fig. 3, 4, and 5.

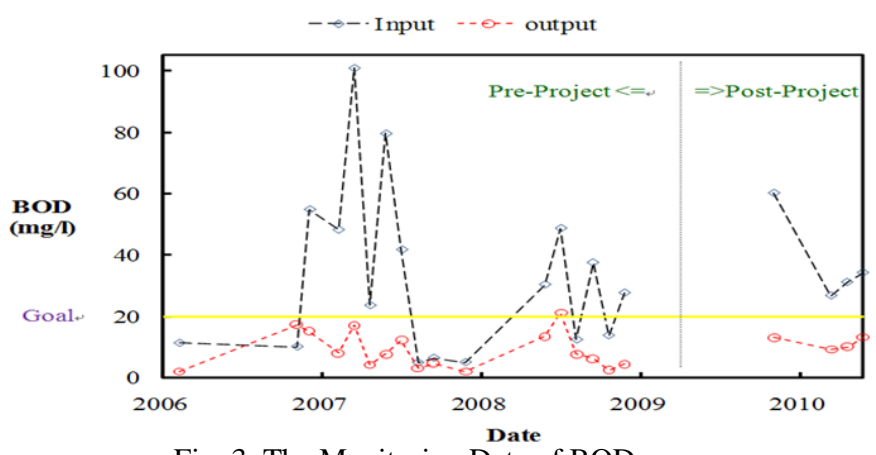

Fig. 3 The Monitoring Data of BOD

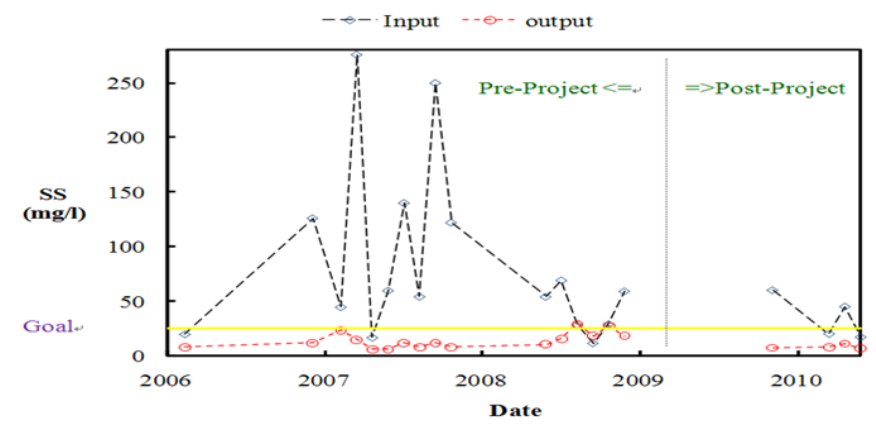

Fig. 4 The Monitoring Data of SS 


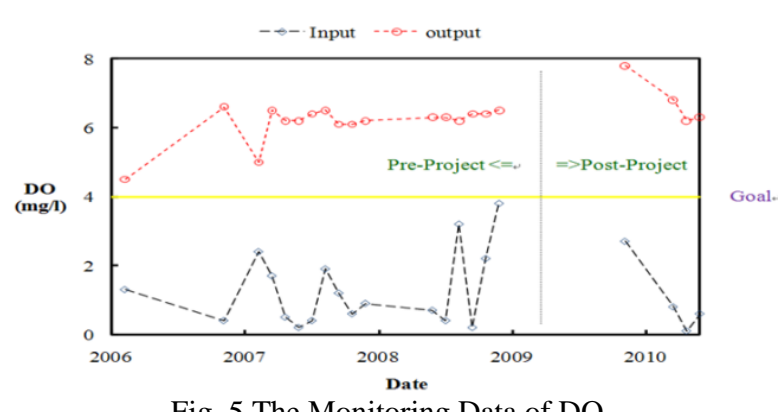

Fig. 5 The Monitoring Data of DO

Based on the performance assessment standards, the intended goals of the water treatment have been achieved. However, the results do not reflect thoroughly the water quality because, according to the administrative officer of the An-Shun Wastewater Treatment Plant, some fishes, such as Tilapia and catfish, could not survive the ecological pond water more than three hours because the water may contain unknown toxic chemicals.

\section{Post Project Appraisal (PPA)}

The results of PPA in The An-Shun Wastewater Treatment Plant Improvement Project analysis was shown in Table 2.

TABLE II.

THE RESULTS OF PPA

\begin{tabular}{|c|c|c|}
\hline Component & Classification & Note \\
\hline Success Criteria & (O) & $\begin{array}{l}\text { The success criteria for water } \\
\text { quality improvement, were } \\
\text { not very complete because } \\
\text { the goals centered on BOD, } \\
\text { DO and SS. }\end{array}$ \\
\hline Preproject Data & $\bullet$ & - \\
\hline Design Rationale & (2) & $\begin{array}{l}\text { The design rationale did not } \\
\text { consider whether the HRT of } \\
\text { wetland system is enough or } \\
\text { not for the increased } \\
\text { discharge. }\end{array}$ \\
\hline Design Drawings & $\bullet$ & - \\
\hline As-Built Drawings & (2) & $\begin{array}{l}\text { The ecological pond did not } \\
\text { appear in the design drawing. }\end{array}$ \\
\hline $\begin{array}{c}\text { Reproducible } \\
\text { Monitoring Program }\end{array}$ & (2) & $\begin{array}{l}\text { The monitoring and } \\
\text { management programs will } \\
\text { take place in the future two } \\
\text { years only. }\end{array}$ \\
\hline
\end{tabular}

•: Good; () : Medium; o: Poor

\section{SWOT Analysis}

Analyses of the strength, weakness, potentials, and threats, or known as the SWOT is necessary to formulate a strategy for solving the water quality problem in the An Shun Drainage Channel.

Strength:

a) The capacity of the An Shun Drainage Channel is sufficient enough to carry both wastewater and rainwater.

b) There is a wastewater treatment plant to reduce the pollutants from wastewater flowing into the channel.

c) The willingness of the government to solve the water quality problem.

d) The government provides some data for monitoring the channel.
Weaknesses:

a) There are no strict regulations to control the channel.

b) The effectiveness of the wastewater treatment plant is not quite good enough to reduce all pollutants from the channel.

c) There is no specific land use plan is the area

Opportunities:

a) There is some financial support from the government.

b) The dredging always reduces the sediment deposited in the channel.

Threats:

a) It is difficult to cooperate between the local government and the community to establish an interactive dialog for solving the problem.

b) There is a lack of the public awareness for improving the water quality in the channel.

\section{V.CONCLUSIONS}

At the present time, the water quality in the An-Shun Drainage Channel remains uncertain. Even though the targeted quality levels for the effluents of the An-Shun Wastewater Treatment Plant have been achieved, it is found that no fish could survive this water condition. The other pollution parameters such as phosphate $(\mathrm{P})$ and nitrate $(\mathrm{N})$ levels should be included in the future monitoring program because fertilizer, and wastes from pets and farm animals are typical sources of excess nutrients in this channel. Excessive levels of the nutrients sharply stimulate aquatic plant and algae growth. Bacterial respiration and organic decomposition can use up dissolved oxygen, depriving fish and invertebrates of the available oxygen in water.

It is necessary to integrate the rehabilitation of the An-Shun Drainage Channel with the Urban Planning Process. The quality of water in the An-Shun Drainage Channel cannot improve by itself, so the stakeholders should initiate some water quality improvement programs and maintain a strong cooperation between them. As the short-term measures, it is needed to develop the monitoring and management projects to control and regulate the wastewater derived from human activities in the riparian area, as an adaptive management. For the long-term measures, it is necessary to separate the wastewater and the rainwater via the sewage treatment system.

\section{REFERENCES}

[1] R. Y. Tallar and J. P. Suen, "Identification of Waterbody Status in Indonesia by Using Predictive Index Assessment Tool', Int. Soil and Water Conservation Research. pp. 224-238, Sept. 2015.

[2] R.Y. Tallar and J. P. Suen, "Aquaculture Water Quality Index: A LowCost Index to Accelerate Aquaculture Development in Indonesia", Aq. Int. pp. 1-18 June 2015.

[3] Tainan City Government. (2010). The Achievement of An-Shun Water Treatment System. (in Chinese)

[4] Wang H. W., (2010), Post-Project Appraisals, handouts for Restoration of Rivers and Streams, Department of Hydraulic and Ocean Engineering, National Cheng-Kung University

[5] Philip Williams and Associates Ltd., (2002), Post-Project Appraisals in Adaptive Management of River Channel Restoration, Springer New York.

[6] Suen, J. P. , (2010), River Health, handouts for Courses of Ecological Water Resourses Management, Department of Hydraulic and Ocean Engineering, National Cheng-Kung University. 